\title{
Current Understanding of Ozone Use for Disinfecting Hemodialysis Water Treatment Systems
}

\author{
Faissal Tarrass $^{\mathrm{a}}$ Meryem Benjelloun ${ }^{\mathrm{a}}$ Omar Benjelloun $^{\mathrm{b}}$ \\ a Department of Dialysis, Hospital Princess Lala Meryem, Larache, Morocco; ${ }^{b}$ Department of Nephrology, \\ Hospital Universitario Central de Asturias, Oviedo, Spain
}

Key Words

Ozone $\cdot$ Disinfection $\cdot$ Water treatment $\cdot$ Hemodialysis

\begin{abstract}
Background: Water treatment systems are susceptible to microbial contaminations and periodical disinfection procedures are mandatory to obtain results requested from international standards. According to the Association for the Advancement of Medical Instrumentation, ozone is the most effective method to destroy microorganisms, and to prevent, reduce or remove the biofilm. This study aims to review the literature on the application of ozone in the disinfection of water treatment systems for hemodialysis. Methods: Data were obtained from databases (Ovid MEDLINE, Cochrane, EMBASE, and others). Results: Ozone is quite effective in killing bacteria and degrading endotoxins and biofilm, with efficacy being concentration- and time-dependent. However, being a strong oxidant, appropriately compatible materials should be used. Also ozone production should be monitored and its level in ambient air should also be checked periodically to maintain a contamination air standard of $0.1 \mathrm{ppm}$. Conclusion: Ozone appears to be promising in hemodialysis. However, further investigations are necessary to approve its wider use.

Copyright $\odot 2010$ S. Karger AG, Basel
\end{abstract}

\section{Introduction}

Ozone $\left(\mathrm{O}_{3}\right)$ is a naturally occurring compound consisting of three oxygen atoms. It is found in nature in the form of a gas in the stratosphere in a concentration of 1-10 ppm, being continually created from and destroyed into molecular $\mathrm{O}_{2}$ [1]. Both these chemical reactions are catalyzed by very-high-frequency ultraviolet light from sunlight. Consequently harmful ultraviolet radiations in the stratosphere reaching the outer atmosphere from the sun are absorbed by ozone $[1,2]$. Therefore, ozone in the stratosphere plays a critical role in both the thermal structure of the stratosphere as well as the ecological framework for life on the earth's surface $[1,3]$.

Recently ozone has received much attention as an alternative disinfection to chlorine due to its quicker powerful microbial activity [4-6]. In hemodialysis, ozone can be used to disinfect water treatment systems, machines or for cleaning dialysate concentrate containers [6-11]. Despite this increasing interest in ozone as a promising method for water disinfection in hemodialysis, the published literature on this subject is very limited.

We have conducted a comprehensive literature search of databases Ovid MEDLINE and its allied versions, $\mathrm{Cu}-$ mulative Index to Nursing \& Allied Health Literature, Evidence-Based Medicine of Cochrane Central Register

Dr. Faissal Tarrass

2 Route Taddart

Rés Bughari, No. 7

20100 Casablanca (Morocco)

Tel. +212 6661494 94, E-Mail ftarrass@ hotmail.com 
Table 1. Selected physical proprieties of ozone

\begin{tabular}{ll}
\hline Property & Characteristic \\
\hline Color & $\begin{array}{l}\text { Gas: blue colored } \\
\text { Dissolved in water: purple blue } \\
\text { at a concentration of }>20 \mathrm{ppm}\end{array}$ \\
& 48 \\
Molecular weight, $\mathrm{g} / \mathrm{mol}$ & 2.144 \\
Density, $\mathrm{kg} / \mathrm{m}^{3}$ & 0.64 \\
Solubility in water at $0^{\circ} \mathrm{C}$ & $-112(161.3)$ \\
Boiling point, ${ }^{\circ} \mathrm{C}(\mathrm{K})$ & 2.08 \\
Electrochemical potential, $\mathrm{V}$ & \\
\hline
\end{tabular}

Table 2. Compatibility of ozone with piping materials used in water distribution systems

\begin{tabular}{ll}
\hline Material & Compatibility with $\mathrm{O}_{3}$ \\
\hline PVC & - \\
CPVC & + \\
PEX & - \\
PP & - \\
PE & - \\
PTFE & + \\
PVDF & + \\
Stainless steel & + \\
Glass & +
\end{tabular}

PVC = Polyvinylchloride CPVC $=$ chlorinated polyvinylchloride; $\mathrm{PVDF}=$ polyvinylidene fluoride PEX = cross-linked polyethylene; $\mathrm{SS}=$ stainless steel; $\mathrm{PP}=$ polypropylene; $\mathrm{PE}=$ polyethylene; $\mathrm{ABS}=$ acrylonitrile butadiene styrene; $\mathrm{PTFE}=$ polytetrafluoroethylene. + = Compatible; $-=$ incompatible.

of Controlled Trials, Cochrane Database of Systematic Reviews, EMBASE, HealthSTAR/Ovid Healthstar, and internet resource of Google Scholar ${ }^{\mathrm{TM}}$ (from their inception until December 31, 2009) to study the permissibility of using ozone as a disinfectant for dialysis water. After removing duplicates as well as reviewing the titles and abstracts of the retrieved articles, six papers were found to be relevant for our objectives. Two additional articles were obtained by searching the bibliographies of the relevant references.

This review is structured as follows: firstly, an assessment of the basic concepts that are essential to understanding how ozone works; followed by the technical aspects of ozone use in hemodialysis; then the safety issues associated with ozone exposure, and finally the practical application of ozone in hemodialysis.

Ozone for Disinfecting Hemodialysis

Water Treatment Systems

\section{Proprieties and Structure of Ozone}

\section{Physical Proprieties}

Ozone is a tri-atomic allotrope of oxygen commonly referred to as $\mathrm{O}_{3}$. It is a highly unstable gas in the thermodynamic conditions of the earth's surface. It has, at a low concentration, a pleasant 'clean' smell originally described as the 'thunder smell' by the Greek poet Homer; while, at higher concentrations, it is deeply irritating. At these concentrations, its color is dark blue. Its density compared with air is 1.657 and it solidifies at a temperature of $-192^{\circ} \mathrm{C}$. Its boiling point at atmospheric pressure is $-112^{\circ} \mathrm{C}$. The molecule is far more unstable when dissolved in water (half-life $4 \mathrm{~min}$ at $20^{\circ} \mathrm{C}$ ) than in air (halflife $14 \mathrm{~h}$ at the same temperature). For further discussion, it is important to know that its solubility decreases as temperature increases, from $1,400 \mathrm{mg} / \mathrm{l}$ at $0^{\circ} \mathrm{C}$ to nil at $70^{\circ} \mathrm{C}[12]$.

The formula is usually written as $\mathrm{O}_{3}$, but in fact the third oxygen atom orbits around the molecular oxygen di-atomic structure. This means that the bond linking the third atom to the molecule structure is very weak and explains why the molecule is so highly reactive. It also explains the easy decomposition of the molecule and recombination of its constituents into a more stable molecular oxygen [12]. The physical characteristics of ozone are listed in table 1.

\section{Material Compatibility of Ozone}

Ozone is a strong oxidant that can destroy numerous types of materials. For instance, ozone is listed as noncompatible with polyvinylchloride (PVC), the material used in most distribution pipes [7, 13]. However, at the low levels used for disinfection purposes, PVC is not affected $[7,10,14]$. Ozone will also attack and oxidize most plastics, elastomeric $\mathrm{O}$ rings and seals $[7,13]$. Therefore, the use of ozone is suitable with the systems which are constructed from appropriately resistant materials, such as chlorinated PVC, polytetrafluoroethylene, polyvinylidene fluoride or stainless steel (AISI type 316L) [7, 13, 14]. This limitation applies not only to the piping and any storage tank that may be in the system, but also to all pumps, valves, and other fittings, including any $\mathrm{O}$ rings and seals they may contain $[7,13]$. Table 2 displays the compatibility of ozone with a wide variety of materials.

\section{Disinfectant Properties}

Ozone is extremely effective as disinfectant, with a performance far superior to sodium hypochlorite, formaldehyde and peracetic acid, commonly used in sanitiz- 
Table 3. Antimicrobial effectiveness of ozone, represented as time (min) to kill an initial number of germs of $1,000 / \mathrm{ml}$

\begin{tabular}{llllll}
\hline $\begin{array}{l}\text { Ozone } \\
\text { concentration } \\
\text { ppb }\end{array}$ & $\begin{array}{l}\text { Staphylococ- Micrococcus } \\
\text { cusaureus } \\
\text { min }\end{array}$ & $\begin{array}{l}\text { luteus } \\
\text { min }\end{array}$ & $\begin{array}{l}\text { Bacillus } \\
\text { subtilis } \\
\text { min }\end{array}$ & $\begin{array}{l}\text { Serratia } \\
\text { marcescens } \\
\text { min }\end{array}$ & $\begin{array}{l}\text { Pseudomonas } \\
\text { aeruginosa } \\
\text { min }\end{array}$ \\
\hline $25-50$ & 60 & 120 & 180 & 180 & 180 \\
100 & 40 & 90 & 120 & 120 & 120 \\
200 & 20 & 40 & 50 & 60 & 90 \\
$1,000-2,000$ & 10 & 10 & 20 & 15 & 20 \\
$4,000-5,000$ & 1 & 1 & 1 & 1 & 1 \\
\hline
\end{tabular}

Adapted from Friedman [18]

\section{Ozone Generation}

Ozone is an unstable gas that rapidly decomposes to return to its oxygen molecule [1]. Due to this characteristic, it cannot be stored or packed in a container, but must be generated on-site and used immediately [22].

In the generation of $\mathrm{O}_{3}$ for commercial applications, a corona discharge is widely used. In this technique, shown in figure 1, dry air or $\mathrm{O}_{2}$ is passed between two electrodes separated by a glass or ceramic dielectric mineral. Concentrations ranging from 1 to $3 \%$ are produced if the feed gas is air and $2-6 \%$ if the feed gas is pure $\mathrm{O}_{2}[16,23]$. Although less common than a corona discharge, $\mathrm{O}_{3}$ may be generated by photochemical, electrolytic and radiochemical means $[16,23]$.

\section{Design of an Ozonation System for Hemodialysis}

The four primary components of an ozonation system used in water treatment are shown in figure 2. They include: the feed-gas supply, ozone generation, ozone injection or contaction, and destruction of excess ozone [22].

\section{Ozone Generation}

An ozone generator comprises three main blocks: an automatic air drying unit, a high-voltage transformer and an ozone generator tube [24]. This generating unit produces gaseous ozone, which is injected into the water in a controlled flow rate through an injector [24].

The ozone generator for hemodialysis application should use oxygen as a feed gas. Air cannot be used because by containing $78 \%$ nitrogen, the final gas mixture will contain a variable amount of highly toxic nitrogen oxides, besides oxygen and ozone [23].

\section{Ozone Injection or Contaction}

The ozone contactor transfers the ozone-rich gas into the water to be treated, and provides contact time for disinfection [24]. Once ozone gas is transferred into water, the dissolved ozone reacts with the organic and inorganic constituents, including any pathogens. Ozone not transferred into the process water during contacting is released from the contactor as off-gas. Transfer efficiencies of $>80 \%$ typically are required for efficient ozone disinfection [24]. imited biofilm kill. Destruction of biofilm may be possible if super-oxidative concentrations can be achieved [20]. However, a high ozone level can reduce the lifetime of some materials [20]. 


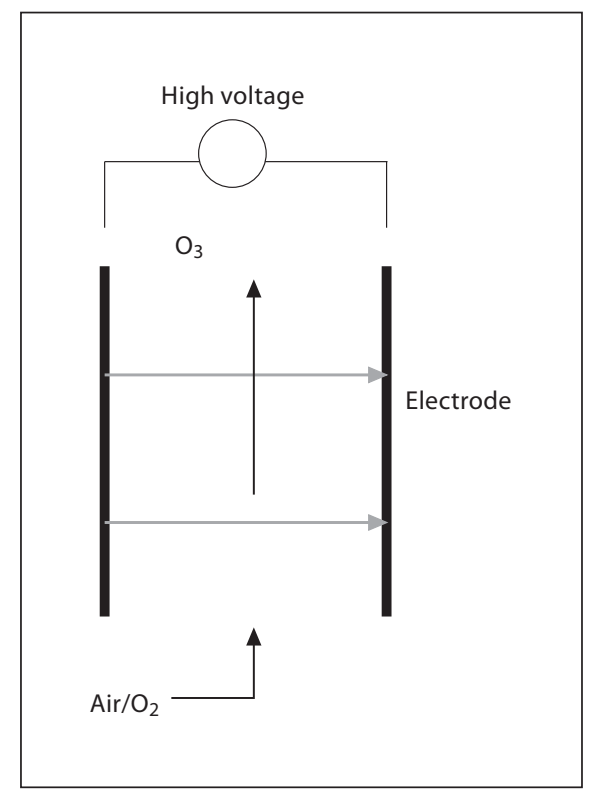

Fig. 1. Corona discharge.

\section{Destruction of Excess Ozone}

Ozone in product water may be harmful to patients, and the product water should not be used until the ozone produced has dissipated [5]. Approaches to remove ozone from the water use UV irradiation [7, 24]. Through the process the $\mathrm{O}_{3}$ molecule is broken down into an $\mathrm{O}_{2}$ molecule plus an $\mathrm{O}$ atom, which will bond to another atom to form a new oxygen molecule [24]. The effectiveness of UV irradiation depends on the dose of radiant energy [5].

Other safety approaches for removing ozone if any molecules are still present in water include temperature $[7,25]$, since ozone above $30^{\circ} \mathrm{C}$ breaks up instantly, or the combination of water with an acidic solution in which ozone will be reduced, and oxidizing acetic acid present in the solution $[7,25]$.

\section{Ozone Measurement and Control}

Dissolved ozone can be monitored and controlled using oxidation-reduction potential analyzers, UV spectrophotometers, colorimeters or sensors that measure the photochemical reaction of ozone with ethylene [25]. The Association for the Advancement of Medical Instrumentation recommend the use of an indigo trisulfonate colorimetric test, or the equivalent, with measurement each time disinfection is performed, and the use of an ozone in ambient air test on a periodic basis to ensure compli-

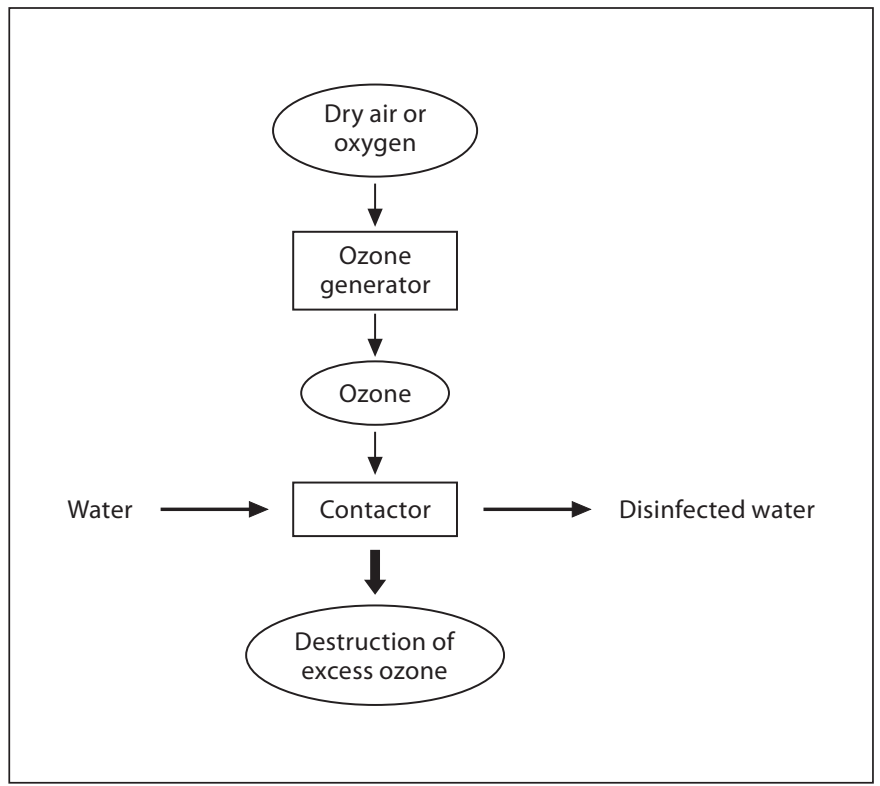

Fig. 2. Basic diagram of the ozonation process (adapted from Solsona [22]).

ance with the permissible exposure limit of $0.1 \mathrm{ppm}$ of the Occupational Safety and Health Administration [14]. The figure 3 is a schematic design of an ozonation water treatment system for hemodialysis application.

\section{Safety Issues Associated with Ozone Exposure}

\section{Patient Safety}

Ozone has a very short half-life of about $25 \mathrm{~min}$ at $20^{\circ} \mathrm{C}$ in highly purified water, and exposure to UV irradiation will quickly remove it [14]. To ensure the complete removal of ozone, the ozone input should be discontinued a minimum of $1 \mathrm{~h}$ before starting up the dialysis water circulation [6]. Additionally, all dialysis water must first pass through an UV light unit. The radiant energy of the UV lamp causes the almost instantaneous breakdown of the ozone back to molecular oxygen. Finally, the dialysis machine itself de-aerates the water as one of its primary functions [6].

\section{Operating Safety}

Safety considerations for operating an ozone system include potential for ozone exposure. Ozone is a toxic gas. It can be smelled at concentrations as low as $0.02-0.04$ $\mathrm{ppm}$. The toxicity threshold is around $0.4 \mathrm{ppm}$ [12]. This 


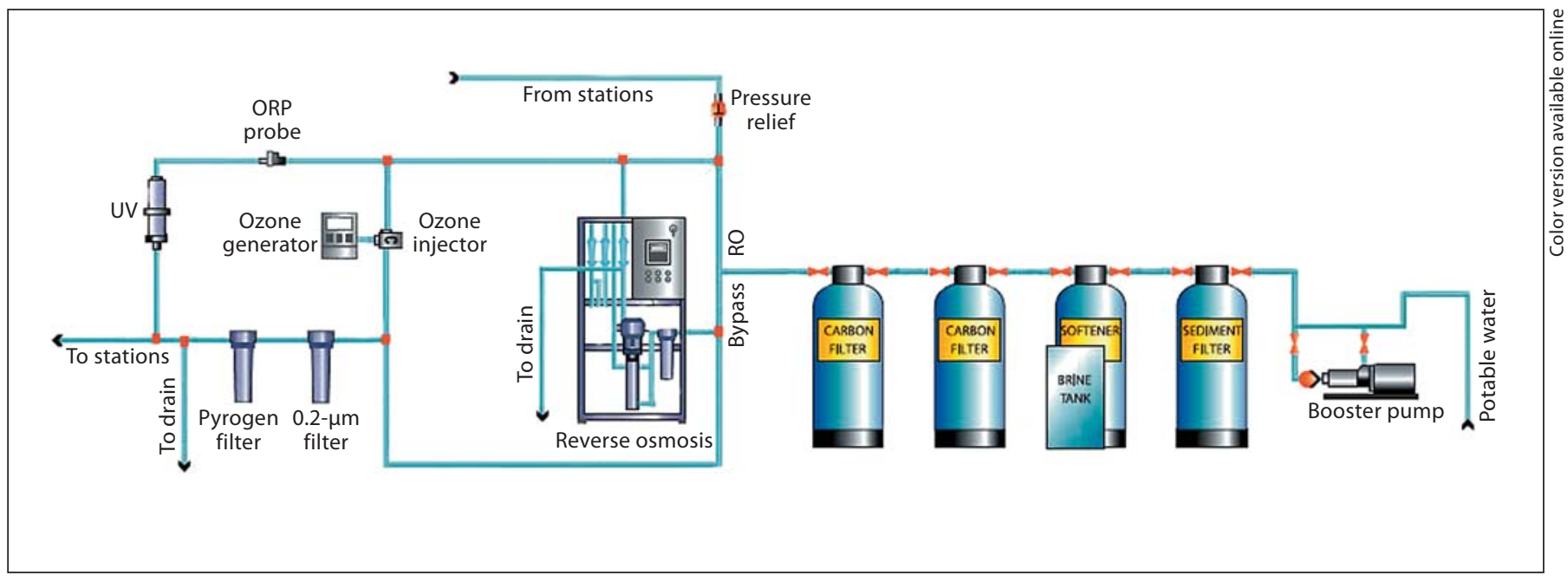

Fig. 3. Design of an ozonation water treatment system for hemodialysis.

Table 4. Comparison between ozone and other disinfectants commonly used in hemodialysis

\begin{tabular}{|c|c|c|c|c|c|c|}
\hline & Ozone & Peracetic acid & Hypochlorite & Chlorine & Formaldehyde & Heat \\
\hline Cycle time, $\min$ & $10-20$ & $30-45$ & & & & 120 \\
\hline Energy consumption & Moderate & No & No & No & No & High \\
\hline Compatible materials & $\begin{array}{l}\text { PVC (low concen- } \\
\text { tration), PVDF, SS }\end{array}$ & $\begin{array}{l}\text { PVC, PVDF, PEX, } \\
\text { PP, PE, ABS }\end{array}$ & $\begin{array}{l}\text { PVC, PVDF, } \\
\text { PEX, PP, PE }\end{array}$ & $\begin{array}{l}\text { PVC, PVDF, } \\
\text { PEX, PP, PE }\end{array}$ & $\begin{array}{l}\text { PVC, PVDF, } \\
\text { PEX, PP, PE, SS }\end{array}$ & $\begin{array}{l}\text { PVDF, } \\
\text { PEX, SS }\end{array}$ \\
\hline Bactericidal & Good & Good & Good & Good & Good & Good \\
\hline Virucidal & Good & Good & Good & Moderate & Moderate & Good \\
\hline Biofilm removing & Yes & No & No & No & No & No \\
\hline Environmental friendly & Yes & No & No & No & No & Yes \\
\hline
\end{tabular}

$\mathrm{ABS}=$ Acrylonitrile butadiene styrene; $\mathrm{PEX}=$ cross-linked polyethylene $\mathrm{PE}=$ polyethylene $\mathrm{PP}=$ polypropylene; $\mathrm{PVC}=$ polyvinylchloride; PVDF = polyvinylidene fluoride; SS = stainless steel.

means that the presence of ozone can be detected at a concentration ten times lower than the minimum toxicity level, which represents a security factor when compared with ethylene oxide gas [12].

Occupational regulations in most countries have set the maximum threshold concentration for permanent exposure to a level of 0.1-0.2 ppm [12]. At higher concentrations, ozone induces ocular and respiratory irritation which could be irreversible if exposure exceeds $24 \mathrm{~h}$ at a concentration exceeding 1 ppm [12].

\section{Practical Application of Ozone in Hemodialysis}

Ozone appears to be one of the most promising 'nonchemical' methods for water systems disinfection in hemodialysis. Recently, an increasing number of dialysis units in Europe (i.e. all Swiss cantonal hospitals) [18] and the United States $[6,7,24]$ are using ozone to disinfect their water distribution systems and dialysate concentrate containers. Results from practical applications of ozone in hemodialysis facilities have shown that ozone is effective and cost-saving for use in treating dialysis water $[18,24]$. 
Table 5. Cost analysis of daily water disinfection with ozone as compared with pasteurization in a dialysis facility working with 12 stations

\begin{tabular}{lcc}
\hline & Ozone & $\begin{array}{l}\text { Heat pasteuri- } \\
\text { zation }(\text { temper- } \\
\left.\text { ature }>80^{\circ} \mathrm{C}\right)\end{array}$ \\
\hline Installed capacity, kW & 0.25 & 50 \\
Energy consumption/operation, kW & 0.06 & 100 \\
Energy consumption/year, kW & 18 & 30,000 \\
Annual costs, EUR & 1.44 & 2,400
\end{tabular}

Adapted from Friedman [18]

Comparison with Other Disinfectants Used in Dialysis

A number of studies confirmed that molecular ozone is a very effective and promising disinfectant in hemodialysis, perhaps better than chlorine dioxide, peracetic acid, sodium hypochlorite, and formaldehyde. A comparison of ozone with these sterilization agents is given in the table 4.

\section{Operational Considerations}

Every night after finishing hemodialysis ozone can be used through an ozone generator for disinfection of the distribution loop, tanks and the concentrate delivery sys- tem [11]. For adequate disinfection of water treatment systems the NANT Dialysis Technology manual recommends: 1 ppm ozone for $10 \mathrm{~min}$ or $0.5 \mathrm{ppm}$ ozone for 20 $\min [26]$. The presence and absence of ozone in the water and ambient air can be monitored regularly by tests (indigo trisulfonate or a digital colorimeter) [11].

\section{Cost Analysis}

All the data we were able to obtain from the literature indicated that ozone is cost-effective for treating dialysis water as compared with other methods such as disinfection with peracetic acid or heat disinfection [18]. Based on a daily routine, Friedman [18] has compared the cost of ozonation with heat pasteurization (temperature $>80^{\circ} \mathrm{C}$ ) for disinfection of water in a facility working with 12 stations. As shown in table 5, ozonation appears more economical than heat pasteurization with regard to energy consumption and total annual costs [18].

\section{Conclusion}

Due to its strong oxidizing activity, the use of ozone appears to be a promising resolution in the control of microbial activity, endotoxins and biofilm in water treatment plants. However, in spite of this positive biological effects, further investigations are necessary in order to approve its wider use in hemodialysis.

\section{References}

1 Azarpazhooh A, Limeback H: The application of ozone in dentistry: a systematic review of literature. J Dent 2008;36:104-106.

2 Bocci V: How ozone acts and how it exerts therapeutic effects; in Lynch E (ed): Ozone: The Revolution in Dentistry. London, Quintessence, 2004, pp 15-22.

$>3$ Solomon S: Stratospheric ozone depletion: a review of concepts and history. Rev Geophys 1999;37:275-316.

4 Clifford WG: The Handbook of Chlorination and Alternative Disinfectants. New York, Wiley, 1999.

5 Hoenicha NA, Robert L: Water treatment for dialysis: technology and clinical implications; in Ronco C, Cruz DN (eds): Hemodialysis - From Basic Research to Clinical Trials. Contrib Nephrol. Basel, Karger, 2008, vol 161, pp 1-6.

6 Edward J: Ozone: the alternative for clean dialysis water. Dial Transplant 1998;27:706712 .
Amato R, Curtis A: The practical application of ozone in dialysis. Nephrol News Issues 2002;16:27-29.

8 Amato RL: Disinfection of an RO system: clearing the issues. Dial Transplant 24:244249.

9 dos Santos F, Biernat JC, dos Santos AM, et al: Desinfection of hemodialysis machines with ozone. J Bras Nefrol 2007;29:14-18.

-10 Cappelli G, Riccardi M, Perrone S, Bondi M, Ligabue G, Albertazzi A: Water treatment and monitor disinfection. Hemodial Int 2006;10:S13-S18.

11 Han SW, Yi JH, Kim HJ: Current status of central concentrate delivery system for hemodialysis in Korea. Blood Purif 2009; 27(suppl 1):70-73.

12 Dusseau JY, Duroselle P, Freney J: Gaseous sterilization; in Fraise AP, Lambert PA, Maillard JY (eds): Russell, Hugo \& Ayliffe's - Principles and Practice of Disinfection, Preservation and Sterilization, ed 4. Oxford, Blackwell, 2004, pp 401-435.
13 Murphy JC: Materials compatibility for ozone. Water Cond Purif 1998;40(5).

14 Association for the Advancement of Medical Instrumentation (AAMI): Dialysate for Hemodialysis. Arlington, ANSI/AAMI RD52, 2004.

15 Biernat JC, dos Santos F, dos Santos AM, et al: Amiloidose por hemodiálise: o que pode mudar com ozônio e água ultra-pura? Sua Revista Virtual de Medicina 2001. http:// www.medonline.com.br/biern1.htm, assessed January 16, 2010.

16 Weavers LK, Wickramanayake GB: Disinfection and sterilization using ozone; in Block SS (ed): Disinfection, Sterilization and Preservation. Philadelphia, Lippincott, Williams \& Wilkins, 2001, pp 205-214. 
17 Rutala WA, Weber DJ, et al: The Guideline for Disinfection and Sterilization in Healthcare Facilities, 2008. Atlanta, Healthcare Infection Control Practices Advisory Committee (HICPAC), 2008.

18 Friedman P: L'ozone en hémodialyse. J Assoc Tech Dial 2004;21. http://www.dialyse.asso. fr/journaux/juin04/article_4.htm, assessed January 16, 2010.

19 Rezaee A, Ghanizadeh G, Yazdanbakhsh $A R$, et al: Removal of endotoxin in water using ozonation process. Aust J Basic Appl Sci 2008;2:495-499.
20 Shirtliff M, Leid JG: The Role of Biofilms in Device-Related Infections. Berlin, Springer, 2009.

21 Barnes RL, Caskey DK: Using ozone in the prevention of bacterial biofilm formation and scaling. Water Cond Purif 2002.

22 Solsona F, Méndez JP: Ozone; in Pan American Center for Sanitary Engineering and Environmental Sciences (eds): Water Disinfection. Lima, Pan American Center for Sanitary Engineering and Environmental Sciences, 2003, pp 69-78.
23 Bocci V: Ozone: A New Medical Drug. Berlin, Springer, 2005.

24 Baratharaj V: Ozone and dialysis water. www.otsil.net/articles/misc\%20-01.pdf, assessed January 16, 2010.

25 Gottschalk C, Libra JA, Saupe A: Ozonation of Water and Waste Water: A Practical Guide to Understanding Ozone and Its Application. Weinheim, Wiley-VCH, 2000.

26 Curtis J, Varughese P: NANT Dialysis Technology: A Manual for Dialysis Technicians. National Association of Nephrology Technicians (NANT), 2000. 